\title{
HAN-ERA FUNERARY ART OBJECTS - WORKS OF BRONZE. HAN-ERA BRONZE AESTHETICS
}

Summary: Speaking of bronze here we refer to various objects made of bronze which is an alloy composed of pure copper and tin, which contains a small fraction of lead. Because bronze is an alloy, its melting point is at a lower temperature than that of pure copper, but the material itself is harder. Ji jin ${ }^{1}$ (吉金) ritual metal vessels, mentioned in ancient Chinese sources are in fact works of bronze. The invention of bronze alloys was an event of epochal historical importance. Thus, the period from the invention of bronze to ubiquitous use of iron is called the Bronze Age.

The Bronze Age in China began with the birth of the Chinese civilization. It lasted until the end of Han dynasty and had several stages of development. Works of bronze

The Bronze Age in China began ${ }^{1}$ with the birth of the Chinese civilization. It lasted until the end of Han dynasty and had several stages of development. Works of bronze first appeared in China in slave-owning society of Xia-Shang (夏商2070 BC), and reached its zenith at the peak of slave-owning system at the end of Shang (商) and the beginning of Zhou. At the end of Chunqiu (春秋475 BC) the slave-owning system began to decline, and the production of bronze items dwindled. By the end of Zhanguo (战国circa 221 BC) works of bronze mainly ritual objects - disappeared from the pages of history. During Qin and Han periods（秦汉221 BC 220 AD) ritual significance of bronze items gradually decreased. Such items got more and more use as everyday household utensils. At the same time Qin and Han is notable for great variety of bronze items' types - they were articles of daily use in the Emperor's palace, money, lanterns, mirrors. These items first appeared during Eastern Zhou period,

1. Ji jin (吉金) - old name for ritual bronze vessels used for sacrifices in Ancient China first appeared in China in slave-owning society of XiaShang (夏商2070 BC), and reached its zenith at the peak of slave-owning system at the end of Shang (商) and the beginning of Zhou. After the end of Chunqiu period (春 秋475 BC) the slave-owning system began to decline, and the production of bronze items dwindled.

In comparison to Shang and Zhou (周朝) bronze, Han objects are much smaller in size because during this period their primary purpose was to be used in common everyday life. Mystical, solemn and even somewhat barbaric bronze of Shang and Zhou was replaced by modest, practical and convenient household utensils.

Keywords: Han dynasty, works of bronze, Han-era culture, mystic utensils.

but they changed their form and appearance in the hundreds of years of Ancient China's history. Han's bronze has some distinctive features, which - it is worth noting - often serve as an inspiration for modern artists.

In comparison to Shang and Zhou (周朝) bronze, Han objects are much smaller in size because during this period their primary purpose was to be used in common everyday life. Mystical, solemn and even somewhat barbaric bronze of Shang and Zhou was replaced by modest, practical and convenient household utensils. By the Eastern Han period, with the spread of lacquerware and ironware, as well as appearance of porcelain in the middle of Eastern Han, the status of bronze items significantly decreased. Bronzeware during Han period both in its variety and style and artistic properties reflected the progress of Chinese society, retreat from mythical mindset and liberalization of public opinion - it is evident from the way the function of bronze items changed. Han period witnessed the departure from the ritual and sacred significance of bronze. 


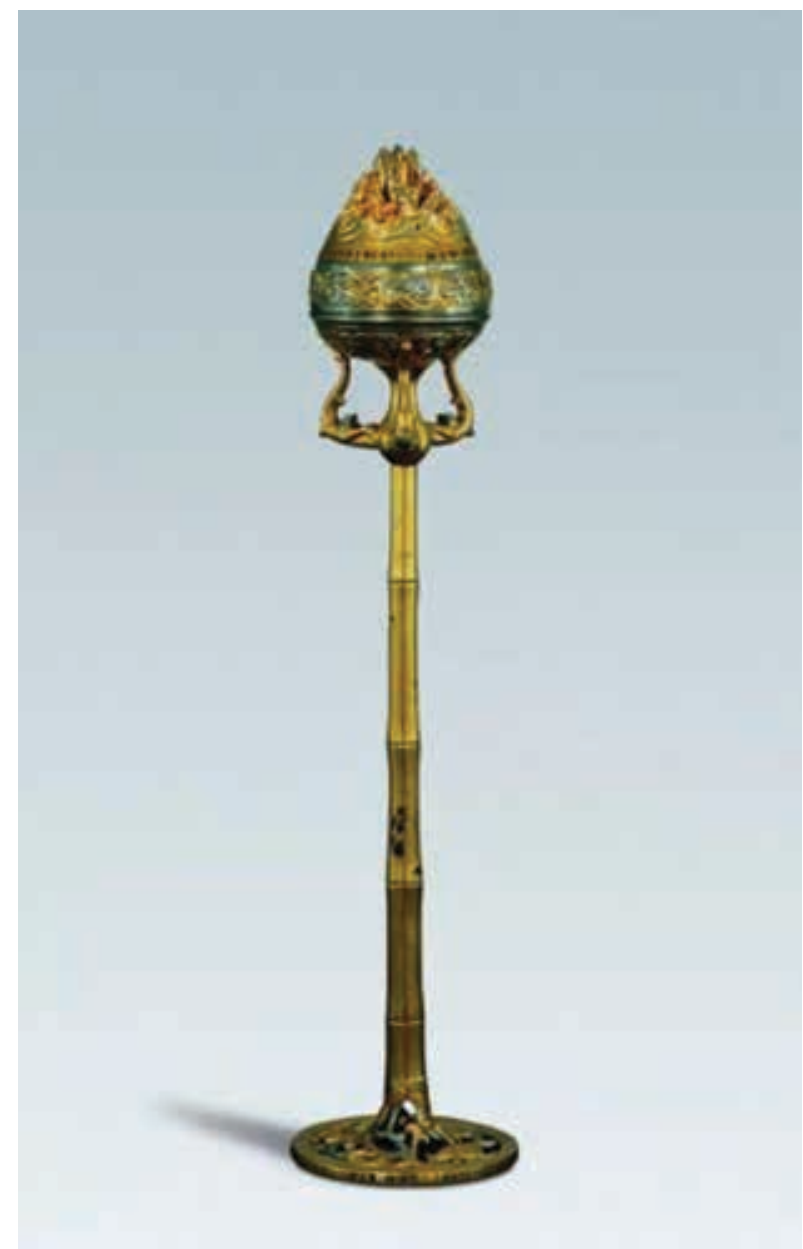

III. 1. Western Han (138 BC), gilded boshan lu incense burner with bamboo stem. $58 \mathrm{~cm}$ in height, the diameter of the bowl at the top is $9 \mathrm{~cm}$, the diameter of the base is $13.3 \mathrm{~cm}$. Found in the Maoling burial. Shaanxi History Museum

Han-era bronze household items were mainly intended for the Emperor's palace due to their high cost of production. As a rule, ornaments and decorative fixtures reflect object's functionality. An example of that is a gilded ${ }^{2}$ bronze censer on a support shaped as bamboo nodes which was found in one of the Maoling 茂陵 tombs (prov. Shanxi $\square$ Xingping 陕西口兴平) (Fig. 1). Due to its mountain-shaped lid this type of item is called boshan-lu (博山炉), i.e. Bo mountain ${ }^{3}$ shaped censer.

The height of the censer is $58 \mathrm{~cm}$, it has a hemispheric bowl, its lid is shaped like Boshan mountain and decorated with multilayered openwork picturing mountain peaks with small crevices in them. When incense was burnt in the censer, the smoke would come

2. Gilding on bronze-during the period in question bronze was gilded with charcoal, mercury and heavy metals which were baked and then transferred to the surface of the object. Therefore, the top layer on a bronze object could be made of gold or silver.

3. Bo Mountain, (博山) Boshan mountain - according to ancient Chinese sources, one of the three sacred places where the celestial beings dwell (Boshan 博山, Yingzhou 瀛洲, Penglai蓬莱)

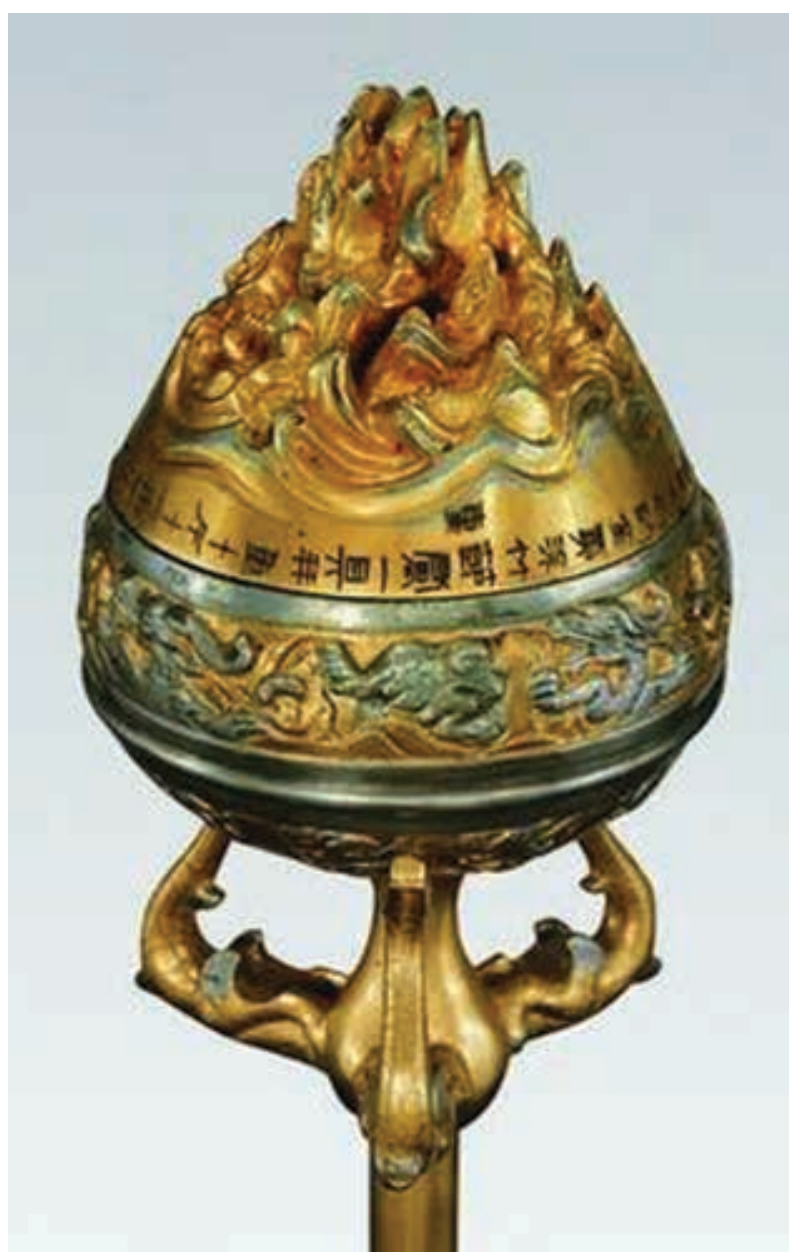

IIl. 2. Western Han (138 BC), gilded boshan lu incense burner with bamboo stem. Fragment

out of these crevices. The lower part of the censer bowl is decorated with an ornament depicting curled dragons - four golden dragons on a silver-plated background, their bodies wriggling. Ornament lines are delicate and easy, decorative fixtures are artfully crafted (Fig. 2). The bowl of the censer rests on a gilded bronze support shaped as bamboo nodes with three wriggling dragons at the top. The support is thicker at the bottom and consists of five nodes. The base is decorated with openwork, depicting two dragons who open their mouths wide to bite the bamboo.

The custom to burn incense existed in China since ancient times. Incenses were burnt not only to create a pleasant atmosphere, but also because floating aromatic incense smoke created a feeling of being close to the world of celestial beings. Such is this censer on bamboo support, with its golden and silver mountain peaks emitting thin flows of smoke, resembling some fantasy scenery. The bamboo support is there to create this dreamlike otherworldly feeling among these mountain peaks. 


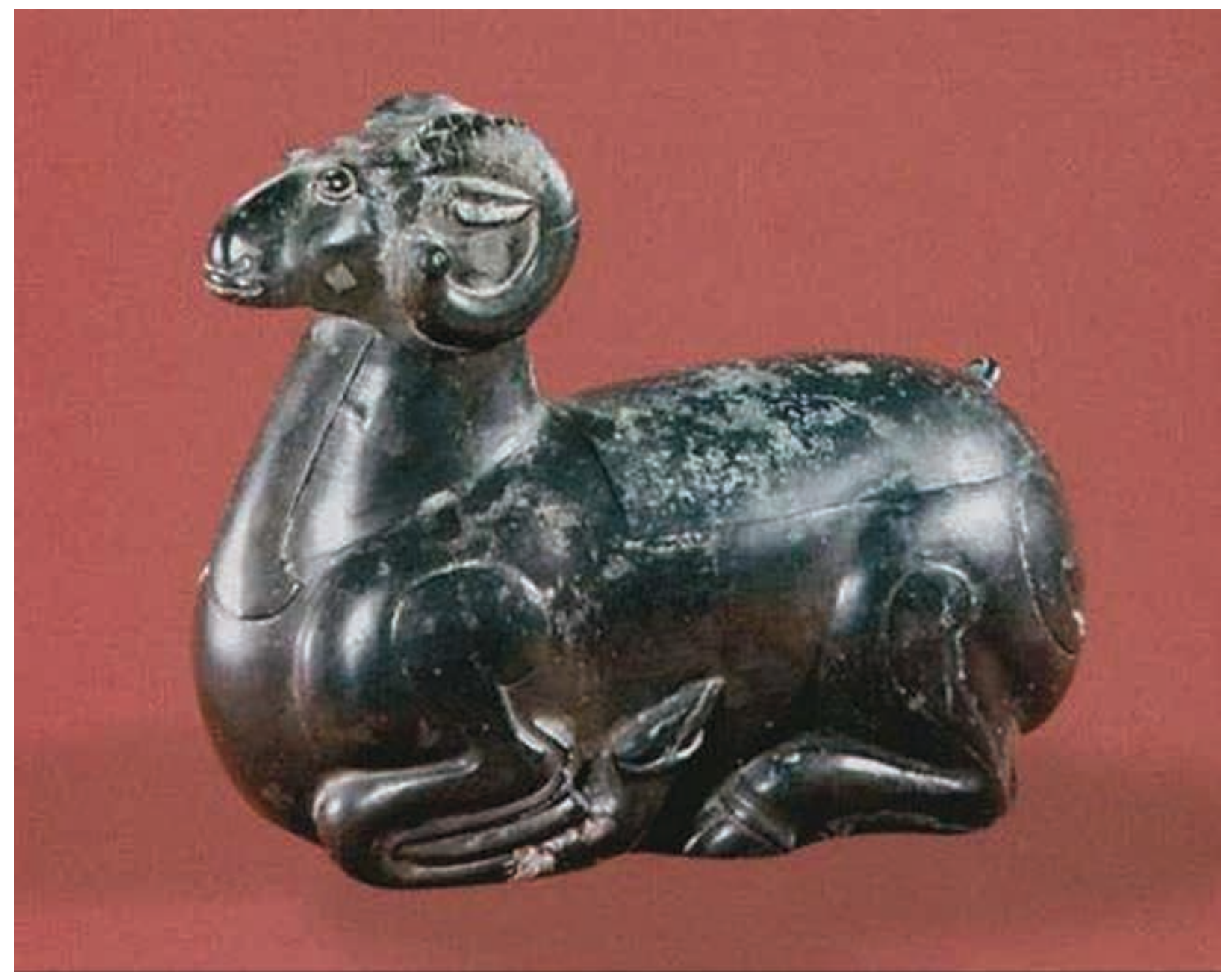

Ill. 3. Western Han. Bronze lamp in the shape of a ram. Height $18.6 \mathrm{~cm}$, Length $23 \mathrm{~cm}$. Found in 1968 in a Han burial in Mancheng. Hebei Provincial Museum

Light mist (thin streams of incense smoke) enveloping finely carved mountains enhanced this effect and made the lid of this censer truly like the mythical Boshan mountain. It is worth noting that boshan-lu censers appeared and became popular during Han period precisely due to the belief in celestial beings, which the rulers of Western Han adhered to and sought to become immortal and turn into celestial beings themselves.

Han-era left a great many of bronze items worth of a work of art status. Wide use of bronze for household items enrichened its style and artistic variety. Many various items with motifs of auspiciousness and good omen appeared, often with images of domestic cattle, phoenixes, turtles, cranes and qilin ${ }^{4}$ (麒麟). There were also rams who were believed to be auspicious animals in ancient Chinese tradition. A typical illustration of that is a lantern shaped

4. Qilin (麒麟) - the auspicious animal in Chinese Tradition. People in Ancient China believed that Qilin appearance brings luck. Sometimes the word qilin is used to describe a person of great talent and dignity. as a lying ram of the Western Han period found in the tomb of prince Zhongshan Liu Sheng（中山靖 王刘胜) (Fig. 3).

The lantern is shaped as a ram lying on its knees with its head raised high. Its head is adorned with two coiled horns, it has a short tail and oval body without any ornament. The body and back of the ram were cast separately and then joined together. The hollow space within its body contained lamp fuel. When the lantern was used, the back of the ram was lifted by the special handle and put on the ram's head (Fig. 4), creating a sort of bowl for the lantern. This piece had small channel to which a wick could be attached, so that when the light went out the remaining oil could be drained through this channel back into the lantern and the bowl was put back in its place to form the ram's back again.

The form of the lantern is well-balanced, the ram has a finished and substantial image. When lit, the lantern created an atmosphere of serenity and safety. As this example illustrates, the way of life during Han-era was reflected with finest detail in the 


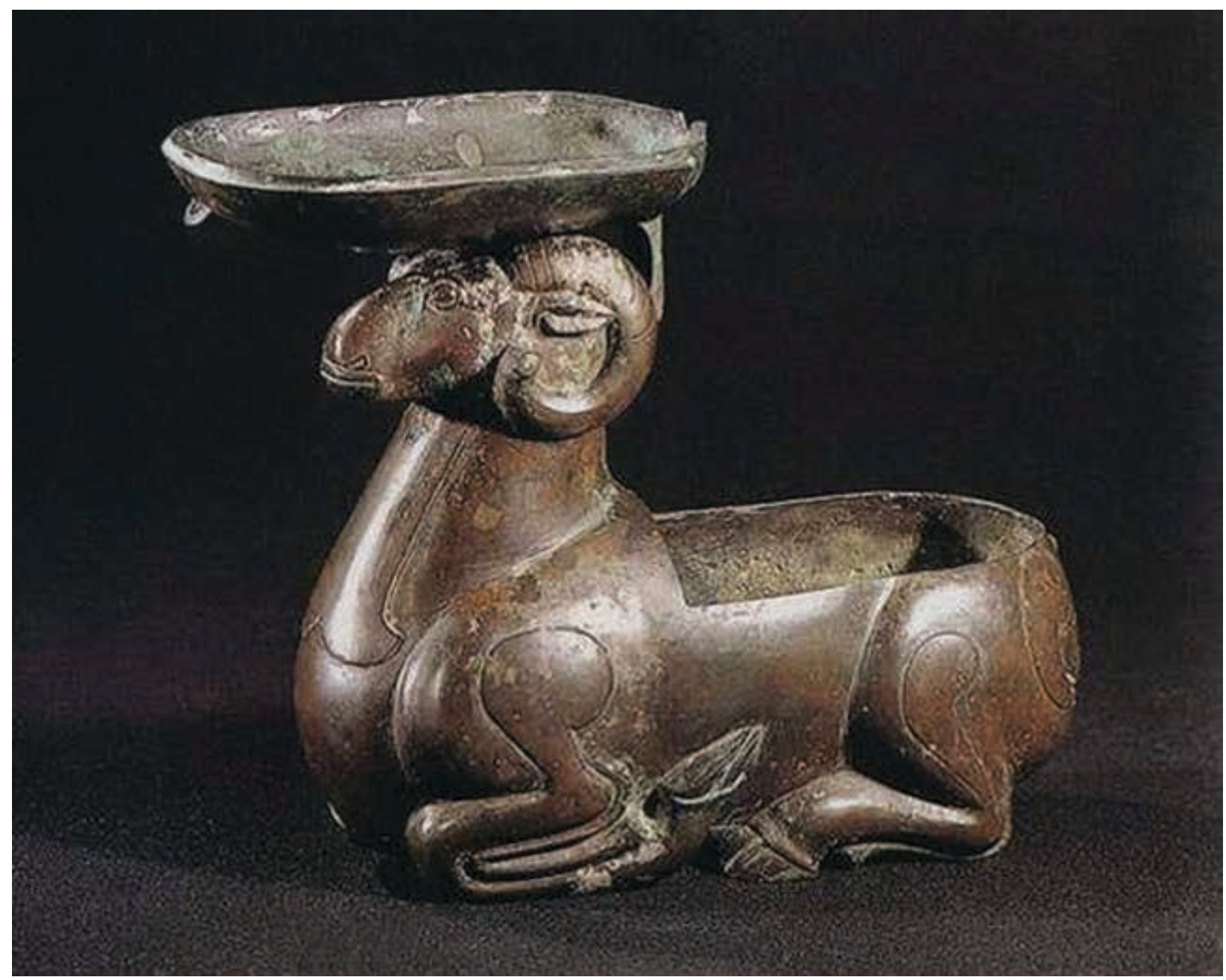

IIl. 4. Western Han. Bronze lamp in the shape of a ram

articles of daily use. The structure of this lantern with its removable bowl goes to show that during this period usability and practicality were the main requirement for any such item. The general motif in bronze item design in Han was the functionality, which was no less important than the exterior of the item.

The history of bronze casting in China dates back to antiquity. The changes in culture and aesthetic vision during Han period changed the functionality of bronze items as well - from articles 'for gods' they turned into things 'for people'. In time, having lost its sacred meaning, they went from mysticism to mundaneness - from temple sacrificial wares with its solemnity to simple and lightweight household utensils, from big and heavy to small and handy objects. Everything in Han bronze - from the form to the ornament and artistic expression features - is aimed at the fellow person and its use by one. It illustrates the change in the mindset that makes the mortal person more significant.

More than four hundred years of Han were also the last time the bronze flourished in the history of China. Bronze objects were created with great craftsmanship which required profound ingenuity and precise scientific calculations. Craftsmen from every Chinese province worked in their unique and rich style with specific inimitable artistic peculiarities. Han bronze has its own characteristic features as well. Bronze items of Han-era and their artistic style laid the background for the development of art in subsequent eras, because from this moment its focus shifted more to everyday life and the individual person. 


\section{REFERENCES}

1. Liu Junyong, Liu Tingting. 2012. "Han Material Culture in Dalian Region", Liaoning Pedagogical University Newsletter, no.1, 2012. 1. 刘俊勇, 刘婷婷, 大连地 区汉代物质文化研究，辽宁师范大学学报，2012年1期.

2. Li Xin. 2010. "Science and Art of Bronze Item Design in Ancient China", Yishu Yu She Ji, no.4. 李鈢, 古典青 铜器设计中的科学性与艺术性的统一, 艺术与设计, 2010 年4期.

3. Wang Jiashu. 1994. Applied Arts in China, Beijing: Wenhua Yishu Publishing House, p. 211. 王家树，中国工艺 美术，北京，文化艺术出版社，1994，211页.

4. Gao Feng. 1988. Applied Arts in China, Beijing: Gongyi Meishu Publishing House 高丰, 中国工艺美术研究, 北 京, 工艺美术出版社, 1998.
5. Wang Xianqian. 2012. Commentary on Zhuangzi A Collection of Wisemen Treatises, Beijing: Zhonghua Shuju，p. 65. 王先谦，庄子集解-诸子集成，北京，中华书 局, 2012, 65页.

6. Yu Weichao. 2001. General review of bronze in Qin and Han, Beijing: Wenwu Publishing House, p. 56. 俞伟超, 秦汉青铜器概论，北京，文物出版社，2001，56页.

7. Wang Zhongshu. 2001. Han-era Archaeology Digest, Beijing: Zhonghua Shuju, 2001, p. 7. 王仲殊. 汉代考古 学概说，北京，中华书局，2001.

8. Zhang Jing. 2004. Brief History of Design, Chongqing: Chongqing University Press，张晶，设计简史，重庆，重 庆大学出版社, 2004. 
Цю Мубин

Московская государственная художественно-промышленная академия им. С. Г. Строганова

e-mail: 493781521@qq.com

г. Шицзячжуан, Китай

ORCHID 000-0002-5699-7562

\section{ПРЕДМЕТЫ ПОГРЕБАЛЬНОГО КУЛЬТА В ЭПОХУ ХАНЬ - ИЗДЕЛИЯ ИЗ БРОНЗЫ. ЭСТЕТИКА БРОНЗЫ В ЭПОХУ ХАНЬ}

\begin{abstract}
Аннотация. Говоря о бронзе, мы в данном случае имеем в виду разнообразные изделия, сделанные из бронзы, то есть сплава чистой меди и олова, в котором присутствует небольшая доля свинца. Так как это сплав, температура плавления у бронзы ниже, чем у чистой меди, при этом материал тверже. Ритуальные металлические сосуды «цзи цзинь» ${ }^{1}$ (吉金), упоминаемые в древнекитайских источниках, - это именно изделия из бронзы. Изобретение сплава бронзы было событием эпохальной, исторической важности. Поэтому в археологии период от изобретения бронзы до повсеместного распространения железа называется «бронзовым веком».

В Китае бронзовый век начался с возникновением китайской цивилизации и длился до конца эпохи Хань, развиваясь поэтапно. Бронзовые изделия впервые появились в Китае в рабовладельческом обще-
\end{abstract}

В Китае бронзовый век ${ }^{1}$ начался с возникновением китайской цивилизации и длился до конца эпохи Хань, развиваясь поэтапно. Бронзовые изделия впервые появились в Китае в рабовладельческом обществе Ся-Шан (夏商2070 г. до н.э.), достигая расцвета одновременно с пиком развития рабовладельческого строя в конце Шан (商) - начале Чжоу. После периода Чуньцю (春秋 475 г. до н.э.) начался упадок рабовладельческого строя, вместе с тем в сошло на нет и производство бронзовых изделий. К концу Чжаньго (战国ок. 221 г. до н.э.) бронзовые изделия, преимущественно ритуальный инвентарь, покинули страницы истории. В периоды Цинь и Хань

1. «Цзи цзинь» (吉金) - старое название ритуальной бронзовой посуды, которая в Древнем Китае использовалась для жертвоприношений. стве Ся-Шан (夏商2070 г. до н.э.), достигая расцвета одновременно с пиком развития рабовладельческого строя в конце Шан (商) - начале Чжоу. После периода Чуньцю (春秋475 г. до н.э.) начался упадок рабовладельческого строя, вместе с тем сошло на нет и производство бронзовых изделий.

По сравнению с бронзой Шан и Чжоу (周朝), изделия в Хань гораздо меньше по размеру, ведь в этот период они предназначались в первую очередь для того, чтобы их использовали в повседневной жизни. Мистической, торжественной и даже в чем-то варварской бронзе Шан и Чжоу на смену пришла более скромная, практичная и удобная для использования повседневная утварь.

Ключевые слова: династия Хань, изделия из бронзы, культуры эпохи Хань, таинственная утварь.

(秦汉221 г. до н.э. - 220 г.н.э.) ритуальное значение бронзовой утвари постепенно уменьшалось, изделия из бронзы всё больше и больше использовались для обыденных, повседневных нужд. В то же время период Цинь и Хань отличался большим разнообразием видов бронзовых изделий - это были предметы обихода в императорском дворце, деньги, фонари, зеркала. Это были изделия, впервые появившиеся в период Восточной Чжоу, но менявшие форму и вид на протяжении столетий истории Древнего Китая. У ханьской бронзы есть свои отличительные черты, которые, стоит отметить, часто служат вдохновением для современных художников.

По сравнению с бронзой Шан и Чжоу (周朝)， изделия в Хань гораздо меньше по размеру, ведь в этот период они предназначались в первую 
очередь для того, чтобы их использовали в повседневной жизни. Мистической, торжественной и даже в чем-то варварской бронзе Шан и Чжоу на смену пришла более скромная, практичная и удобная для использования повседневная утварь. К Восточной Хань, с распространением лаковых и железных изделий, появлением фарфора в середине Восточной Хань, статус изделий из бронзы значительно понизился. Бронзовая утварь в период династии Хань, и по своему разнообразию, и по стилю и художественным особенностям, отразила прогресс китайского общества, отход от мифического мышления и либерализацию общественного сознания - это видно по тому, как сменялась функция бронзовых изделий. В Хань происходит отход от ритуального, сакрального значения бронзы.

Бронзовые изделия для повседневного пользования в эпоху Хань из-за сравнительно высокой себестоимости при изготовлении в основном предназначались для императорского дворца. Орнаменты и декоративные элементы на этих изделиях, как правило, отражают их функциональное предназначение. В пример стоит привести найденную в одном из захоронений в Маолин 茂陵 (пров. Шэньси, Синпин陕西, 兴平) позолоченную ${ }^{2}$ бронзовую курильницу на подножке в форме коленцев бамбука (ил. 1). Благодаря своей крышке в форме горы такой тип изделия называется «бошань-лу» (博山炉), т.е. «курильница в виде горы Бо» ${ }^{3}$.

Высота курильницы 58 см, чаша полусферическая, крышка сделана в виде горы Бошань и украшена многослойной ажурной резьбой, изображающей пики гор, между которыми есть небольшие зазоры. Когда в курильнице жгли благовония, из этих зазоров выходил дым. Нижняя часть чаши курильницы украшена орнаментом с изображением свернувшихся драконов - это четыре золотых дракона на посеребрённом фоне, тела драконов извиваются. Линии орнамента изящные и свободные, декоративные элементы сделаны с большим мастерством (ил. 2). Чаша курильницы стоит на позолоченной бронзовой

2. Позолота на бронзе - в рассматриваемый период бронзу золотили при помощи древесного угля, ртути и тяжёлых металлов, которые обжигались, а затем наносились на поверхность изделия. Верхний слой на бронзовом изделии таким образом мог быть из золота или серебра.

3. Гора Бо, (博山) гора Бошань - согласно древнекитайским источникам, одно из трёх священных мест на море, где проживают небожители (Бошань 博山, Инчжоу 瀛洲, Пэнлай 蓬莱) ножке в форме коленцев бамбука с тремя извивающимися драконами сверху. Ножка утолщается к низу и состоит из пяти коленцев. Основание украшено резьбой, изображающей двух драконов, широко раскрывающих пасть и вцепившихся зубами в бамбук.

Обычай жечь благовония существовал в Китае с древности. Это делалось не только для создания приятной атмосферы, но ещё и потому, что ароматный и струящийся дым от благовоний создавал ощущение близости к миру небожителей. Так и эта курильница на бамбуковой ножке, с её золотыми и серебряными горными вершинами, из которых струился дым, напоминает некий сказочный пейзаж. Бамбуковая ножка нужна для того, чтобы создать это ощущение сказочности, иномирности горных вершин. Лёгкий туман, окутывающий тонко вырезанные горы (то есть струйки дыма от благовоний), усиливал этот эффект, и действительно уподоблял крышку курильницы мифической горе Бошань. Следует сказать, что курильницы бошань-лу появились и стали популярными в Хань именно благодаря вере в небожителей, которой придерживались правители Западной Хань, и сами искавшие способ достичь бессмертия и стать небожителями.

От эпохи Хань осталось великое множество бронзовых изделий, заслуживающих статуса произведений искусства. Широкое использование бронзы для изготовления повседневной утвари обогатило её стиль и художественное разнообразие. Появилось немало разнообразных изделий с мотивом благовещения и доброго предзнаменования, и часто на них встречаются образы домашнего скота, фениксов, черепах и журавлей, цилиня ${ }^{4}$ (鹿麟). Можно также увидеть и баранов, также считавшихся благовещими животными в древнекитайской традиции. Характерный пример - светильник в виде лежащего барана периода Западной Хань, найденный в могиле принца Чжуншаня Лю Шэна (中山靖王刘胜) (ил. 3).

Светильник изготовлен в форме лежащего на коленях и высоко вскинувшего голову барана. На голове барана два витых рога, хвост короткий, тело овальное, лишённое орнамента. Тело и спина барана были отлиты отдельно и затем соединены вместе. В полое пространство внутри

4. Цилинь (麒麟) - благовещий зверь в китайской традиции. В Древнем Китае верили, что появление цилиня предвещает удачу. Иногда слово «цилинь» используется, когда говорят о выдающемся, талантливом и благородном человеке. 
тела барана помещалось топливо для горения. Когда лампу использовали, спинка барана приподнималась за специальную ручку, снималась и клалась барану на голову (ил. 4), превращаясь в своеобразную чашу для светильника. Эта спинка была оснащена небольшим каналом, к которому можно приставить фитиль, а когда лампа потухала, оставшееся масло сливалось по этому каналу обратно внутрь светильника, чаша переворачивалась и возвращалась на своё место, вновь становясь спиной барана.

Форма светильника гармоничная, образ барана законченный и основательный, когда светильник был зажжён, создавалась атмосфера спокойствия и безопасности. Как видно в случае с данным бронзовым изделием, образ жизни в эпоху Хань до мельчайших крупиц отражался в предметах обихода. Строение светильника, с его съёмной чашей показывает, что в этот период удобство в использовании и практичность были основным требованием к изделию. Главным мотивом в дизайне бронзовых изделий в Хань стала функциональность, которой придавалось не меньшее значение, чем внешнему облику предмета.

История литья бронзы в Китае уходит корнями в глубокую древность. Изменения в культуре и эстетических воззрениях в период Хань изменили и функциональное предназначение изделий из бронзы - из изделий «для богов» они превратились в изделия «для людей». Утратив со временем своё сакральное значение, они прошли путь от мистицизма до обыденности - от храмовой жертвенной посуды с её строгой торжественностью до простой и лёгкой хозяйственной утвари, от больших и тяжёлых изделий до маленьких и практичных. Всё в ханьской бронзе - от формы изделия до орнаментов и художественных средств выразительности - нацелено на человека и использование изделия человеком. Это показывает и смену мировоззрения, при котором человеку придаётся больше значения.

Четыреста с лишним лет истории Хань были также и временем последнего расцвета бронзы в истории Китая. Изделия из бронзы создавались с великим мастерством, требовавшим искусности и точных научных расчётов. Мастера каждой из китайских династий создавали изделия в своём уникальном, богатом стиле, обладающим своими неповторимыми художественными особенностями. Есть свои характерные особенности и у ханьской бронзы. Бронзовые изделия в эпоху Хань и их художественный стиль заложили основу для развития искусства в последующие эпохи, ведь с этого момента оно начало больше фокусироваться на жизни и человеке.

\section{БИБЛИОГРАФИЯ}

1. Лю Цзюньюн, Лю Тинтин. Материальная культура Хань в районе Далянь // Вестник Ляонинского педагогического университета.- № 1, 2012. 刘俊勇, 刘婷婷，大连地区汉代物质文化研究，辽宁师范大学学 报, 2012年1期.

2. Ли Синь. Наука и искусство в дизайне бронзовых изделий Древнего Китая // «Ишу юй шэ цзи».№ 4. - 2010. 李金金, 古典青铜器设计中的科学性与艺 术性的统一，艺术与设计，2010年4期.

3. Ван Цзяшу. Прикладное искусство Китая.- Пекин: Изд. «Вэньхуа ишу», 1994.- C. 211. 王家树, 中国工 艺美术，北京，文化艺术出版社，1994，211页.

4. Гао Фэн. Прикладное искусство Китая.-Пекин: Изд. «Гунъи мэйшу», 1998. 高丰, 中国工艺美术研究, 北京， 工艺美术出版社, 1998
5. Ван Сяньцянь. Комментарии к Чжуан-цзы - сборник трактатов мудрецов. - Пекин: Чжунхуа шуцзю, 2012.－ C. 65. 王先谦，庄子集解-诸子集成，北京，中华 书局, 2012，65页.

6. Юй Вэйчао. Общий обзор бронзы в Цинь и Хань.Пекин: Изд. «Вэньу», 2001. - 56 с. 俞伟超, 秦汉青铜 器概论，北京，文物出版社，2001，56页.

7. Ван Чжуншу. Очерк археологии эпохи Хань.- Пекин: Чжунхуа шуцзю, 2001. С. 7. 王仲殊. 汉代考古学 概说，北京，中华书局，2001.

8. Чжан Цзин. Краткая история дизайна.- Чунцин: Изд. Чунцинского университета, 2004. 张晶, 设计简 史, 重庆, 重庆大学出版社, 2004. 